\title{
Classifier Constructions in English and Kurdish
}

\author{
Anjuman Muhammad Sabir and Dyar Ali Kamal \\ Department of English Language, College of Education, University of Salahaddin, Kurdistan Region-Iraq.
}

Received: 01. 2019 / Accepted: 02. 2019 / Published: 3. 2019 https://doi.org/10.26436/hjuoz.2019.7.1.467

\begin{abstract}
:
Greenberg (1972) in a study based on a sample of about 100 languages with numeral classifiers, attempted to determine the conditions under which anon- classifier language might become a classifier language. Later Hale and Shresthachrya (1973) made their attempts to seek whether Newari is considered as a classifier language or not. The purpose of this study is to analyze the Kurdish classifier system based on the Greenberg (1972) whether Kurdish is a classifier language or not, the paper also compares classifier constructions in English and Kurdish, with the aim of addressing the research questions: what linguistic devices are used in Kurdish and English for classification? How different or similar are classifiers in Kurdish and English as non-classifier language. Classifiers in Kurdish have not been studied extensively and there are not any references available on classifiers of Kurdish in English. Therefore, by considering the classifier system of Kurdish, this study makes attempt to provide an introductory source of analytical research of grammar in Kurdish.
\end{abstract}

Keywords: classifier, non- classifier, counting system, Kurdish.

\section{Introduction}

Languages across the world can be divided into classifier and non-classifier languages in terms of counting system. Count nouns can be quantified directly by a determiner while noncount nouns must take a classifier when they are quantified. Many linguists (lyons1977, Quirk et al 1985, Biber 1999 and Flowerdew and Forest 2015 ) consider classifier as a subclass of nouns in English grammar. Quirk (1985:242-51) and Murcia Freeman (1999:326) refer to it as a partitive noun, while Biber et al (1999:225-7) divide classifier into collective nouns, unit nouns ,quantifying nouns and species noun . In English and in other languages, nouns may vary with respect to the property of countability. Nouns of high countability denote objects which are typically associated with a characteristic shape. In contrast, nouns of low countability denote objects in terms of masses without unitary structure or characteristic shape. Countability bears a number of grammatical consequences, one of which is the way in which nouns may occur in construction with numerals. Nouns of high countability generally occur in direct construction with numerals. In contrast, nouns of low countability typically do not occur in direct construction with numerals; instead, an additional item must be present. Thus while non-classifier languages have two kinds of common nouns, count nouns and mass nouns, classifier languages have only one of the two kinds, mass nouns (Allan1980). In English a classifier is used when individuating masses but it is not obligatory, moreover, mass nouns are used as count nouns, as in
Three coffees please (cups of coffee) bêzhemet sê kup(kup qawe )

Three cups of coffee sê kup qawe

Moreover, the syntactic form of classifier expression in English is

(Det) N1 [ppof (Det)N2]

A bunch of bananas

Where 'of' cannot be replaced by another preposition, nor can it be paraphrased as a compound which reverses the order of the two nouns, where N1 is the syntactic head and 'of' forms a prepositional phrases with the following NP(Lehrer 1986:110). It has been suggested (Greenberg 1972, Allan 1977 and Lehrer 1986) that languages like English are nonclassifier languages, whereas no study has been conducted on Kurdish language.

\section{Implicational Universals}

The paper adopts Greenberg's (1972) implicational universals, to seek the characteristics' of universal language and to determine whether Kurdish has the characteristics of classifier language or not.

A .Non-unit counters : if a language has non-unit counters ,it will be considered as a classifier language,yet languages can have non-unit counters and not be classifier languages such as English and Kurdish which have non-unit counters and are non-classifier languages(see appendix A for Kurdish Alphabet Letters

in

IPA):

\begin{tabular}{l|l}
\hline a herd of cattle & ranêk mê̂ / rane merêk \\
\hline a bunch of grapes & hêşuyek tirê / hêşwe tirêyek \\
\hline a bit of sweets & Parçeyek paqlawe /parçe paqlaweyek \\
\hline a row of beans & dêrawêk fasolya / dêrawe fasolyeyek \\
\hline
\end{tabular}


The examples given above do not prove that Kurdish is a classifier language. They only indicate that Kurdish possesses basis of true classifiers. The Kurdish examples are well matched by similar counters in English, which is a nonclassifier language. In Kurdish both forms are possible, here the allomorphs/ yek/ and /êk/, are modifiers of the qualifier where they have been moved to the final positions of the nouns by an optional T-rule.

B -Quasi-unit-counters; according to Greenberg's' implicational universals, a classifier language will have quasi unit counters. Yet a language can have quasi unit counters and not be a classifier language. He distinguishes two kinds of quasi -unit counters :those which lack wholeness and internal structure and those which function as particulates and have wholeness and internal structure .To illustrate the difference between the two, Greenberg(p.13) states if one cuts a piece of meat in two, one has two pieces of meat but if one cuts a dog in two ,one still has one dog, a dead one .English and Kurdish have both kinds .Consider the following :

A piece of meat $\quad \begin{gathered}\text { parçe goştêk / parçeyek goşt } \\ * \text { A piece of dog }\end{gathered}$ * parçe segêk $/ *$ parçeyek seg

Greenberg further illustrated another kind of borderline case by certain English phrases:

$$
\begin{array}{cc}
\text { A drop of water } & \text { diłope awêk / diłopêk aw } \\
\text { A grain of sand } & \text { mişte limêk / miştêk } \\
\text { A blade of grass } & \text { çiłe giyayek / çiłêk giya }
\end{array}
$$

These particulates as he might call them, are never used in actual counting because of their smallness and lack of individuality. Their universe of numeration is limited to quantifiers ,such as one, a , and none .Kurdish also has Quasiunit counters of this type. Thus ,the examples given above don't prove that Kurdish is a classifier language in that they are similar to English examples, which is a non- classifier language .

C. Measure constructions: non- classifier languages such as English also have measure constructions .Measure constructions often occur with mass nouns, a central characteristics of mass nouns is that they normally do not occur with number but needs intervening measure, Kurdish also has measure constructions though it makes no distinction between mass and count nouns :

$$
\begin{array}{cc}
\text { One cup of coffee } & \text { yek kup qawe } \\
\text { Two gallons of water } & \text { du gałon aw } \\
\text { Three bottles of milk } & \text { sê butł şîr }
\end{array}
$$

Such examples do not prove that Kurdish is a classifier language in that they resemble English ones which is a nonclassifier language.

\section{Characteristics of classifiers:}

Kurdish language may be considered a classifiers or not depending on Greenberg (1972)and Hale and Shresthachrya(1973)

a. Overt expressions of unit counting

English language with its grammatical distinction between mass and countable nouns, makes it possible to count certain nouns by ones .Consider the following nouns :

$\begin{array}{cc}\text { Table } & \text { mêz } \\ \text { Window } & \text { pençere } \\ \text { House } & \text { xanu } \\ \text { Person } & \text { kes } \\ \text { Book } & \text { ktêb }\end{array}$

It is possible to count nouns directly with numbers in English and Kurdish respectively. One is 'yek' and two is 'du'. Thus both languages are similar typologically

$$
\begin{array}{cl}
\text { One house } & \text { yek xanu } \\
\text { One person } & \text { yek kes }
\end{array}
$$

B .Impose a semantic classification upon head nouns .Consider the following:

$\begin{array}{cc}\text { A cup of water } & \text { kupêk aw } \\ \text { A gallon of water } & \text { gałonêk aw } \\ \text { A liter of water } & \text { littrêk aw } \\ \text { A bottle of water } & \text { buttêk aw }\end{array}$

The above classifiers indicate that they don't generally impose a semantic classification upon the same head nouns. Thus the classifiers 'cup/ kup', 'gallon/gałon' 'liter/litr' and 'bottle/butt' generally occur with the same noun heads ,hence both English and Kurdish are similar typologically.

C- function as individualizers of a head which is indeterminate for number. In classifier languages, the classified noun is always singular noun .This characteristics is quite common among classifier languages (Greenberg1972:26), Similar to these is Kurdish language ,where neither the plural nor the numeral classifier construction is obligatory with nouns .Kurdish does not have obligatory marking of the plural nouns, namely the classified noun itself is namely singular. In fact the plural is hardly occur apart from definite nouns. Thus in English the plural or the numeral classifier construction is obligatory with countable nouns as in

$$
\text { A heard of animals rane merêk }
$$

While kurdish patterns as atypical classifier language in this regard ,here it contrasts typologically with English

$$
\begin{array}{r}
\begin{array}{r}
\text { Quantifier }+ \text { Noun }_{\text {sing }}+\text { Determiner } \\
\text { people })
\end{array} \\
\text { çend kesanê ( some } \\
\text { Noun } 1+\text { Determiner kesanêk }
\end{array}
$$

D: No reality outsider of the numeral expression

In classifier language the classifiers have no meaning a part from the construction and have no independent reference to the non-linguistic word.However in non classifier languages such as English, the classifiers have meanings a part from the constructions, e.g.

(Glass / gallon/ liter) of water

Where (glass, gallon, liter) have meanings, similar to English, Kurdish classifiers also have meaning

(Perdax/litr/gałon)êk aw

Hence both languages are similar typologically, these characteristics can be concluded that Kurdish just like English is a non-classifier language and that it has nothing apart from one true classifiers .English and Kurdish do not have classifiers ,however, they have an overt linguistic classifier categorization device, moreover , after a close examination ,English and Kurdish are found to possess words that are very similar to classifier language Like English, Kurdish classifier is not obligatory ,for counting people or animals, classifiers are used in most cases, while for counting things the classifier is optional, consider the following : 
Common

Examples

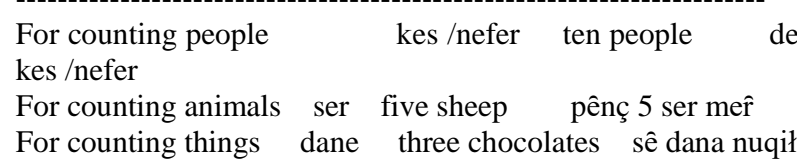

\begin{tabular}{llll}
\hline i. & $\begin{array}{l}\text { [Number]+Quantifier } \\
+\mathrm{N}_{\text {sing }}\end{array}$ \\
\hline & çend kesanê \\
çwar menceł mast & \\
ii. & Quantifier $+\mathrm{e}_{\text {izafe }}+$ Noun $_{\text {sing }}+$ Determiner & \\
\hline
\end{tabular}

Çend mencełe mastêk

iii. Numberpl+Determiner+ êk

kesanêk

The cardinal number can be followed by a classifier which is also followed by the singular noun in the absolute state. $[\mathrm{D} 1+(\mathrm{N}$ [ D2 ] ) N2 ]

(Kim2010:12)

Hence in Kurdish, the classifier often lies between the determiner (cardinal number) and the singular noun ,for example

Two cups of tea.

Du kup ça

\section{Categories of classification}

Allan (1977) and Lehrer (1986) list categories of classifiers in English:

1.unit counter 2.fractional classifiers 3. Numeral set classifiers 4. Collective classifiers 5. Varietal (species )classifiers 6. Measure classifiers and 7.arrangement classifiers

1.Unit classifiers typically co-occur with mass nouns in spite of their occurrences with countable nouns as in:

a piece of cake parçe kêkêk

$$
\begin{array}{cc}
\text { A bar of raisins } & \text { paketêk kişmîş } \\
\text { A bit of sweets } & \text { tozêk şîrînî } \\
\text { a portion of chips } & \text { miştêk çipis }
\end{array}
$$

Likewise in Kurdish, unit counters always occur with singular count or mass nouns .In other words it will not have obligatory marking of the plural on nouns ,namely the classified noun itself is normally singular.

tozêk şîrînî

parçe kêkêk

Other English and Kurdish unit classifiers are ball, loaf, cube ,slice, string ,top, tîke ,parçe ,kert and riste respectively.

2. Fractional classifiers typically occur with mass nouns in English but with mass and countable nouns in Kurdish.

three quarters of the cake sê çarekî kêkeke

sê çarekî birnceke (* three

quarters of the rice)

While number set classifiers like, ten, dozen ,hundred and thousand combine with plural nouns in English and singular( countable /uncountable ) nouns in Kurdish

A dozen of pens

derzenêk qełem

Many hundreds of people

sedan kes

derzenêk şerbet $(*$ a dozen of

juice)

3.Collective classifiers group single entities together so as to provide a collective reference for separate entities (Biber et al 1999:250).The items referred to collective can be people ,animals, or inanimate entities .Collective classifiers typically co-occur with plural count nouns in English while it combines with singular noun in Kurdish.

A herd of animals ranêk mê̂ / rane merêk

(a bunch of grass) Besteyek giya

Lehrer (1986:122)states that varietal classifiers are special category of classifiers in that they denote a quantity and their co-occurrence with singular nouns after 'of' differs from that of other classifiers, the most typical varietal classifiers in English are sort, kind type .Varietal classifiers occur with both mass and count nouns depending on singular and plural classifiers respetively:

A nasty kind of a person

Nasty kinds of people

Unlike English ,Kurdish varietal classifiers is always singular and typically occur with singular noun

\section{Sê cor şerbet}

Sê cor qełem

4. Measure classifiers are referred to as fixed and irregular measures and exact and inexact measures by (Allan 1077 and Lehrer 1986) respectively, the former forms a small closed,while the latter is limitless:

Two pounds of potatoes du kîlo petate

Two cups of tea du kup ça

Measure classifiers combine with mass nouns more frequently than plural countable nouns .In Kurdish the two types of measure classifiers occur with singular nouns

du kîlo petate du kup ça

Arrangement classifiers are similar to collective classifiers in that they also refer to a group and usually co-occur with plural countable nouns. The difference is that collective classifiers focus on the collective aspect of the items in a group, whereas arrangement classifiers focus on the constellation aspect (shape) how the entities are arranged in a group, among arrangement classifiers are stack, row, line, cap and pile .In Kurdish , arrangement classifiers always occur with singular noun :

Two rows of beans du dêraw fasolya

Three piles of books sê deste kitêb

\section{A Contrastive Analysis of Classifiers in English and Kurdish}

Judging from various characteristics of classifiers and nonclassifier languages. English and Kurdish are definitely nonclassifiers languages, because they are only required for mass nouns i.e. they are optional for count nouns . Whereas in Kurdish they are optional for both countable and mass nouns .Moreover, English is a language that makes a morphological distinction between singular and plural nouns or between mass and count nouns at all,whereas Kurdish makes a slight difference between them.

English and Kurdish have the same seven categories of classifiers, in spite of the quantitative similarities in the types and tokens of classifiers used,English and Kurdish differ much qualitatively in their use of classifiers of the seven categories of classifiers ,the most noticeable difference lies in that they only required for non-count nouns in English whereas in Kurdish they are optional for both countable and mass nouns .Other categories of classifiers

are qualitatively more similar than different in the two languages, they have full lexical meanings and can find their counters in the other languages, except that such English classifiers are not restricted to singular forms .

There are a number of syntactic differences in the use of classifiers in English and Kurdish .First ,English classifiers as a special group of nouns have singular and plural forms .while their counterparts in Kurdish do not .Second ,classifiers take a considerably greater variety of modifiers in English and Kurdish. 
Brems (2003:300)distinguishes two major types of classifier modifiers in English, classifier intensifiers such as full ,huge, great, small, little and evaluative quantifiers of $\mathrm{N} 2$ which are regularly relocated to precede classifiers ,such relocation occurs with classifier modifiers in Kurdish

A late -night cup of coffee kupêkî direngeşew qawe

\section{Conclusion}

English and Kurdish are definitely non-classifiers languages, however, they have an overt linguistic classifier categorization device, yet they differ in a number of way for example, they display a some-language -specific syntactic difference. Like English, Kurdish classifier is not obligatory, for counting people or animals, classifiers are used in most cases, while for counting things the classifier is optional. In addition, based on Greenberg's (1972) framework, a syntactically and semantically analysis of classifiers in Kurdish has been done. It is hoped that by doing this analysis further researchers have a good source about classifiers in Kurdish. Next, this study analyzes the classifiers from just a syntactic and semantic point of view and does not consider the pragmatic and discourse of classifiers. Further studies can be done to take these aspects of classifiers into consideration. A contrastive analysis of classifiers, using this study as reference, between English and Kurdish can also be done to find out the transferring problems of Kurdish learners when they want to convert the Kurdish classifiers into English.

\section{References}

Allan,K.,(1977). “Classifier”.Language53,281-311. Nouns and Countability

Allan,K(1980). "Nouns and Countability". Language 56/ 3, 541-567. Biber, D., S. Johansson, G. Leech, S. Conrad and E. Finegan. (1999). Longman Grammar of Spoken and Written English. London: Longman.

Brems ,L.(2003). "MeasureNoun Construction: An Instance of Semantically Driven Grammaticalization": International Journal of Corpus Linguistics 8/2,283-312.

Celce-Murcia,M.and D.Larsen-Freeman (1999). The Grammar Book. Heinle:Heinle .Publishers.

Flowerdew,J.and R.W.Forest. (2015). Signalling Nouns in English :ACorpus -Based Discourse Approach .Cambridge :Cambridge University Press.

Greenberg,J.(1972) “.Numeral Classifiers and Substantival Number :Problems in the Genesis of a Linguistic Type." Working Papers on Language Universals, 1-39

Hale,A.and I Shresthachrya .(1973). "Is Newari a Classifier Language" Contributions to Nepales Studies1(1):1-21.

Kim,D.H. (2010).A Basic Guide to Kurdish Grammar . Hawler .(Culture and Language Institute of Kurdi and Kori)

Lehrer, A. (1986). "English Classifier Construction", Lingua 68,109148.

Lyons, J. (1977).Semantics (1).Cambridge: Cambridge University Press.

Quirk,R.,S.Greenbaum,G.Leech and J.Svartvik(1985) - A Comprehensive Grammar of the English. London: Longman. 
Appendix A

Kurdish Alphabet Letters in IPA

\begin{tabular}{|c|c|}
\hline Universal Kurdish & IPA \\
\hline $\mathrm{A}, \mathrm{a}$ & [a:] \\
\hline $\mathrm{B}, \mathrm{b}$ & [b] \\
\hline $\mathrm{C}, \mathrm{C}$ & [d́s] \\
\hline Ç, ç & [t] \\
\hline$D, d$ & [d] \\
\hline $\mathrm{E}, \mathrm{e}$ & {$[\underline{\varepsilon}]$} \\
\hline$\hat{E}, \hat{e}$ & [e:] \\
\hline$F, f$ & [f] \\
\hline G, g & [g] \\
\hline $\mathrm{H}, \mathrm{h}$ & {$[\mathrm{h}]$} \\
\hline $\mathrm{I}, \mathrm{i}$ & $\mathrm{N} / \mathrm{A}$ \\
\hline$\hat{I}, \hat{\imath}$ & [i: $]$ \\
\hline $\mathrm{J}, \mathrm{j}$ & [3] \\
\hline $\mathrm{K}, \mathrm{k}$ & {$[\mathrm{k}]$} \\
\hline $\mathrm{L}, \mathrm{I}$ & [!] \\
\hline$Ł, \nmid$ & {$[t]$} \\
\hline $\mathrm{M}, \mathrm{m}$ & [m] \\
\hline $\mathrm{N}, \mathrm{n}$ & [n] \\
\hline$\grave{N}$, n̆ & [n] \\
\hline O, o & [0] \\
\hline$P, p$ & [p] \\
\hline Q, q & [a] \\
\hline$R, r$ & {$[c]$} \\
\hline$\check{R}, \check{r}$ & {$[\mathrm{r}]$} \\
\hline $\mathrm{S}, \mathrm{s}$ & [s] \\
\hline Ş, ş & [1] \\
\hline $\mathrm{T}, \mathrm{t}$ & [t] \\
\hline $\mathrm{U}, \mathrm{u}$ & [u] \\
\hline$\hat{U}, \mathrm{u}$ & [ü:] \\
\hline Ü, ü & {$[\mathrm{y}:]$} \\
\hline $\mathrm{V}, \mathrm{v}$ & {$[\mathrm{v}]$} \\
\hline $\mathrm{W}, \mathrm{w}$ & [w] \\
\hline$X, x$ & {$[\underline{x}]$} \\
\hline $\mathrm{Y}, \mathrm{y}$ & [i] \\
\hline $\mathrm{Z}, \mathrm{z}$ & [z] \\
\hline
\end{tabular}




\section{يوّلينكهر له زمانى كوردى و ئينكليزيدا}

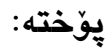

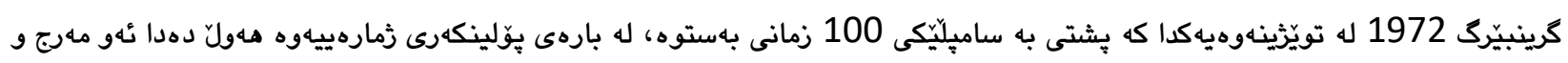

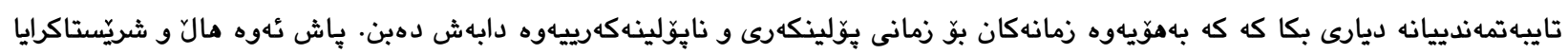

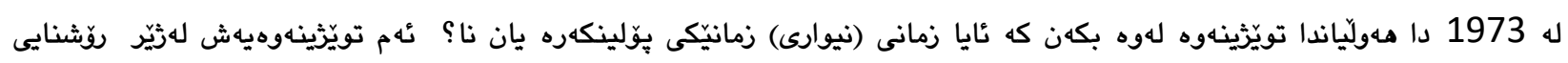

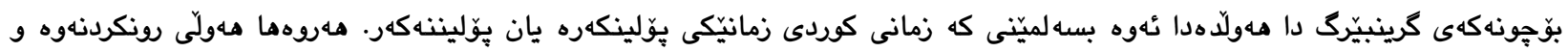

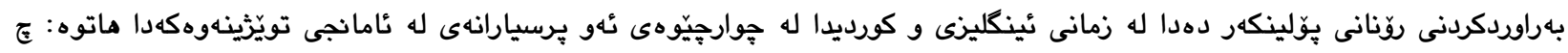

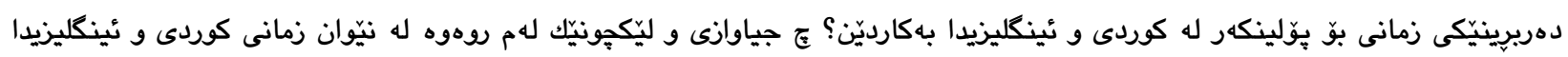

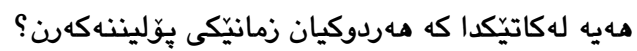

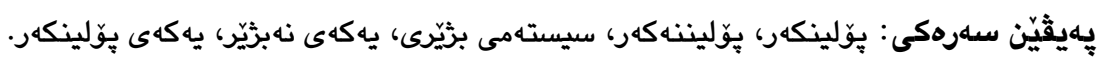

$$
\text { تركيب المصنف الكوردية والإنجليزية }
$$

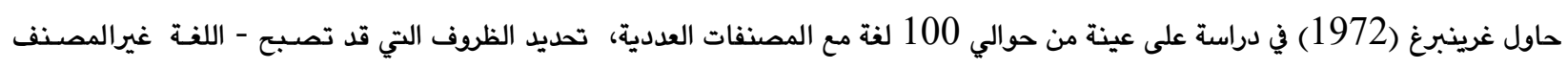

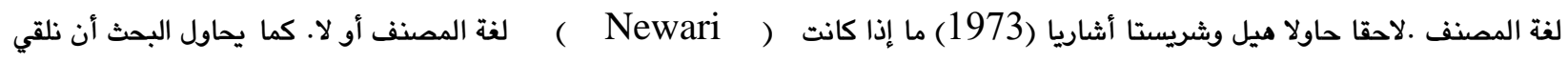

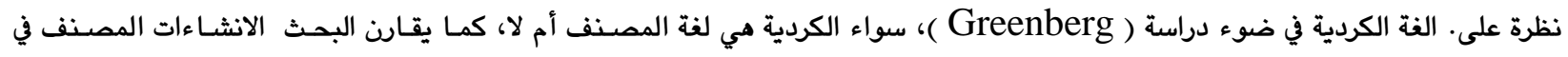

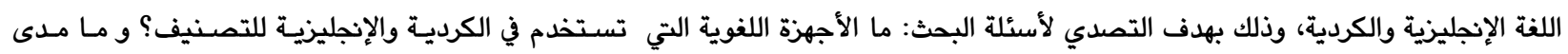
اختلاف أو تشابه المصنفات باللغة الكردية والانكليزيةكلغات غير المصنف. الكلمات الدالة: مصنف، غير مصنف، نظام عد، عدادات غير وحدة، مصنفات الوحدة. 